\title{
Adaptive Silviculture for Climate Change: From Concepts to Reality Report on a symposium held at Carrefour Forêts 2019
}

\author{
by Nelson Thiffault ${ }^{1,2^{*}}$, Patricia Raymond ${ }^{3}$, Jean-Martin Lussier ${ }^{1}$, Isabelle Aubin ${ }^{2,4}$, Samuel Royer-Tardif4, \\ Anthony W. D’Amato ${ }^{5}$, Frédérik Doyon ${ }^{2,6}$, Benoit Lafleur²,7, Martin Perron ${ }^{3,8}$, Jean Bousquet ${ }^{8}$, Nathalie Isabel9,10, \\ Sylvie Carles ${ }^{11}$, Patrick Lupien ${ }^{12}$ and Annie Malenfant ${ }^{13}$
}

\begin{abstract}
As part of the Carrefour Forêts 2019 Conference, the forest research branch of Quebec's Ministère des Forêts, de la Faune et des Parcs and the Canadian Wood Fibre Centre of Natural Resources Canada organized jointly the symposium "Adaptive silviculture to climate change: from concepts to reality". The symposium brought together a hundred actors from the forest sector including engineers, biologists, technicians, private woodlot owners, professors, researchers and students. Speakers from different regions of Quebec and Vermont shared current knowledge related to adaptive silviculture in order to nurture reflexion and dialogue about actions that can be taken today to help forests to adapt with the anticipated changes. The symposium covered the theoretical framework of adaptive silviculture, then offered case studies of different ecosystems, innovative tools or research initiatives. The symposium also included presentations by practitioners who described the challenges and opportunities offered by adaptive silviculture in their professional practice. Based on an interactive discussion, participants identified increased drought events, partial cuttings and mixed-species plantations as important topics on which researchers and practitioners should interact in years to come.
\end{abstract}

Keywords: silvicultural treatments, global change, vulnerability, drought, hardwood forests, mixedwood forests, boreal forests, ecosystem-based management, tree breeding, genomics, implementation, functional ecology

\section{RÉSUMÉ}

Dans le cadre du Carrefour Forêts 2019, le colloque Sylviculture d'adaptation aux changements climatiques : des concepts à la réalité, organisé conjointement par la Direction de la recherche forestière du ministère des Forêts, de la Faune et des Parcs du Québec et le Centre canadien sur la fibre de bois de Ressources naturelles Canada, a rassemblé une centaine d'acteurs du milieu forestier incluant des ingénieurs forestiers, des biologistes, des techniciens forestiers, des propriétaires de boisés, des professeurs, des chercheurs et des étudiants. Des conférenciers de différentes régions du Québec et du Vermont ont partagé les connaissances actuelles en rapport avec la sylviculture d'adaptation afin d'amorcer la réflexion et le dialogue quant aux actions pouvant être entreprises dès maintenant pour favoriser l'adaptation des forêts aux changements anticipés. Les présentations ont abordé les fondements théoriques de la sylviculture d'adaptation, pour ensuite présenter des réflexions ou des études de cas portant sur différents types d'écosystèmes, des outils innovants ou des initiatives de recherche. Le colloque a également laissé une place aux praticiens qui ont pu décrire les défis et les occasions qu'offre la sylviculture d'adaptation dans leur pratique professionnelle. Au terme d'une activité interactive, les participants ont ciblé les sécheresses accrues, les coupes partielles et les plantations mélangées comme des thèmes importants qui devraient animer les échanges entre les chercheurs et les praticiens dans les années à venir.

Mots-clés: traitements sylvicoles, changements globaux, vulnérabilité, sécheresse, forêt décidue, forêt mixte, forêt boréale, aménagement écosystémique, amélioration génétique, génomique, mise en œuvre, écologie fonctionnelle

\footnotetext{
${ }^{1}$ Canadian Wood Fibre Centre, Canadian Forest Service, Natural Resources Canada, 1055 Rue du P.E.P.S., PO Box 10380, Stn. Sainte-Foy, Quebec City, QC, G1V 4C7, Canada; *Corresponding author. Email: nelson.thiffault@canada.ca

${ }^{2}$ Centre d'étude de la forêt, Faculté de foresterie, de géographie et de géomatique, Université Laval, Quebec City, QC, G1V 0A6, Canada

${ }^{3}$ Direction de la recherche forestière, Ministère des Forêts, de la Faune et des Parcs du Québec, 2700 Einstein Street, Quebec City, QC, G1P 3W8, Canada ${ }^{4}$ Great Lakes Forestry Centre, Canadian Forest Service, Natural Resources Canada, 1219 Queen St. E., Sault Ste. Marie, ON, P6A 2E5, Canada ${ }^{5}$ University of Vermont, Rubenstein School of Environment and Natural Resources, 204E, Aiken Center, Burlington, VT, 05405, USA

${ }^{6}$ Université du Québec en Outaouais, Institut des sciences de la forêt tempérée, 58 Principale Street, Ripon, QC, J0V 1V0, Canada

${ }^{7}$ Université du Québec en Abitibi-Témiscamingue, Institut de recherche sur les forêts, 445 Boul. de l'Université, Rouyn-Noranda, QC, J9X 5E4, Canada ${ }^{8}$ Canada Research Chair in Forest Genomics, Université Laval, Faculté de foresterie, de géographie et de géomatique, Université Laval, 1030 Avenue de la Médecine, Quebec City, QC, G1V 0A6, Canada

${ }^{9}$ Département des sciences du bois et de la forêt, Faculté de foresterie, de géographie et de géomatique, Université Laval, Quebec City, QC, G1V 0A6, Canada ${ }^{10}$ Laurentian Forestry Centre, Canadian Forest Service, Natural Resources Canada, 1055 Rue du P.E.P.S., PO Box 10380, Stn. Sainte-Foy, Quebec City, QC, G1V 4C7, Canada

${ }^{11}$ Direction générale de la production de semences et de plants forestiers, Ministère des Forêts, de la Faune et des Parcs, 4 Einstein Street, Quebec City, QC, G1H 6R1, Canada

${ }^{12}$ Syndicat des producteurs de bois de la Mauricie, Lanaudière et du Centre-du-Québec, 2410 Industrie Street, Trois-Rivières, QC, G8Z 4R5, Canada

${ }^{13}$ Direction de la gestion des forêts de la Gaspésie-Îles-de-la-Madeleine, Ministère des Forêts, de la Faune et des Parcs, 195 Perron Blvd. East. Caplan, QC, G0C 1H0, Canada
} 


\section{Introduction}

Observed and future climate change will cause significant stress on forests. Although many of these impacts remain uncertain (Millar et al. 2007; Bonan 2008; Gauthier et al. 2015), it seems clear they will intensify over the decades to come (Price et al. 2013). For example, cases of forest degradation will possibly become more frequent (Allen et al. 2010), with impacts on the interactions between forestry activities, forest cover, soil and pests (Trumbore et al. 2015). Climate change also has intangible but very real effects on forest management activities such as the uncertainty it generates and that must be managed by forest managers and silviculturists (Klenk et al. 2011; Williamson et al. 2019).

Silviculture offers the potential of improving the ability of forests to adapt to climate change (Nagel et al. 2017). Adaptive silviculture is therefore an important tool in the sustainable management of Quebec's forests. As such, several strategies can be explored to promote the resistance, resilience or transition of stands, based on an understanding of their natural dynamics (Millar et al. 2007). While researchers explore the theoretical framework, potential and limits of these various strategies, forest managers and silviculturists face the daily challenge of integrating this new knowledge in their professional practice. However, integrating the most recent scientific developments into practice is not a simple matter (Böcher and Krott 2014).

Within this perspective, Carrefour Forêts 2019, hosted by the Ministère des Forêts, de la Faune et des Parcs du Québec (MFFP), invited more than 1700 participants from the scientific, practical and political spheres of Quebec forestry in order to encourage exchanges between researchers and practitioners (Ministère des Forêts de la Faune et des Parcs 2019). Overall, the Carrefour covered the themes of ecosystem natural dynamics, ecosystem-based management and silviculture, climate change, the integration of social and environmental issues in forestry management, the economic aspects of forestry management in public and private forests as well as innovation and development in the forest products industry. These various themes were addressed in symposiums, workshops, training sessions and a field tour.

As part of Carrefour Forêts 2019, the symposium Adaptive Silviculture for Climate Change: From Concepts to Reality, jointly organized by the MFFP's Forestry Research Branch and Natural Resources Canada's Canadian Wood Fibre Centre, brought together a hundred or so stakeholders from the forestry sector including forestry engineers, biologists, forestry technicians, woodlot owners, professors, researchers and students. Guest speakers from various regions of Quebec and Vermont shared their current knowledge on adaptive silviculture in order to initiate reflection and dialogue regarding the actions that can be taken right now to help forests adapt to the expected changes. The program for the symposium ${ }^{1}$ was developed to cover the theoretical foundations of adaptive silviculture and then present reflections or case studies covering various types of ecosystems, innovative tools or research initiatives. Lastly, the symposium provided a place

\footnotetext{
${ }^{1}$ The program and presentations are available here: https://mffp.gouv.qc.ca/documents/forets/recherche/Actes_Carrefour_Forets_2019.pdf
}

for practitioners to describe the challenges and opportunities offered by adaptive silviculture in their professional practice.

All of the summaries and presentations from the symposium are available online (Ministère des Forêts de la Faune et des Parcs 2019). Our objective in this article is to gather together and disseminate the information that was shared during the symposium to stimulate reflection and promote exchanges. Our hope is to implement a form of silviculture that will help forests adapt and assume a fuller role in the fight against climate change (Lemprière et al. 2013).

\section{Integrated evaluation of the vulnerability of Cana- dian forests to climate change}

Tree species vary in their capacity to tolerate, migrate or adapt to climate change, which will have major consequences on the health and productivity of future forest ecosystems, forest composition and disturbance regimes. However, largescale projections on the impacts of climate change on forests rarely take these aspects of vulnerability into account. Researchers have developed indices based on functional traits that reflect the differences in the sensitivity and adaptive capacity of tree species to key climate stress factors (Fig. 1). They have worked to determine the zones that are vulnerable to drought and migration failure (a species' inability to migrate quickly enough to follow the movement of its climate niche) and the impact on the composition and future productivity of Canadian forests (Fig. 2). This was done by combining climate projections determining the degree of exposure of forests with the sensitivity of species to drought and migration failure (Aubin et al. 2018) ${ }^{2}$. This exercise enabled them to highlight the regional differences that exist in the vulnerability of forests to these two elements.

In addition to the degree of exposure and the sensitivity of species, the vulnerability of forests also depends on the capacity of species to persist in a location under new growth conditions, i.e., their capacity to adapt (Spathelf et al. 2015). The speakers developed a conceptual framework to quantify the adaptive capacity of 26 Canadian tree species based on four adaptation components: 1) the degree of phenotypic plasticity (an organism's capacity to express several characteristics based on various environmental situations); 2) genetic diversity; 3) gene flow within tree populations; and, 4) those between populations.

The development of spatial tools integrating the information pertaining to migration and adaptation sensitivity and capacity is a critical step in the development of adaptation strategies. Work is underway to propose an array of silvicultural options taking into account the vulnerability of ecosystems and the principle of forest zoning to encourage sustainable forest management that makes it possible to achieve a multitude of objectives at a territory-wide level. Speakers proposed several silvicultural approaches representing a gradient of management intensity ranging from maintaining biological reserves in climate refuges to the use of high-performance plantations in a changing climate. The latter would make it possible to preserve the wood fibre supply while promoting

\footnotetext{
${ }^{2}$ And see: https://glfc.cfsnet.nfis.org/fcvul/?\&lang=en
} 


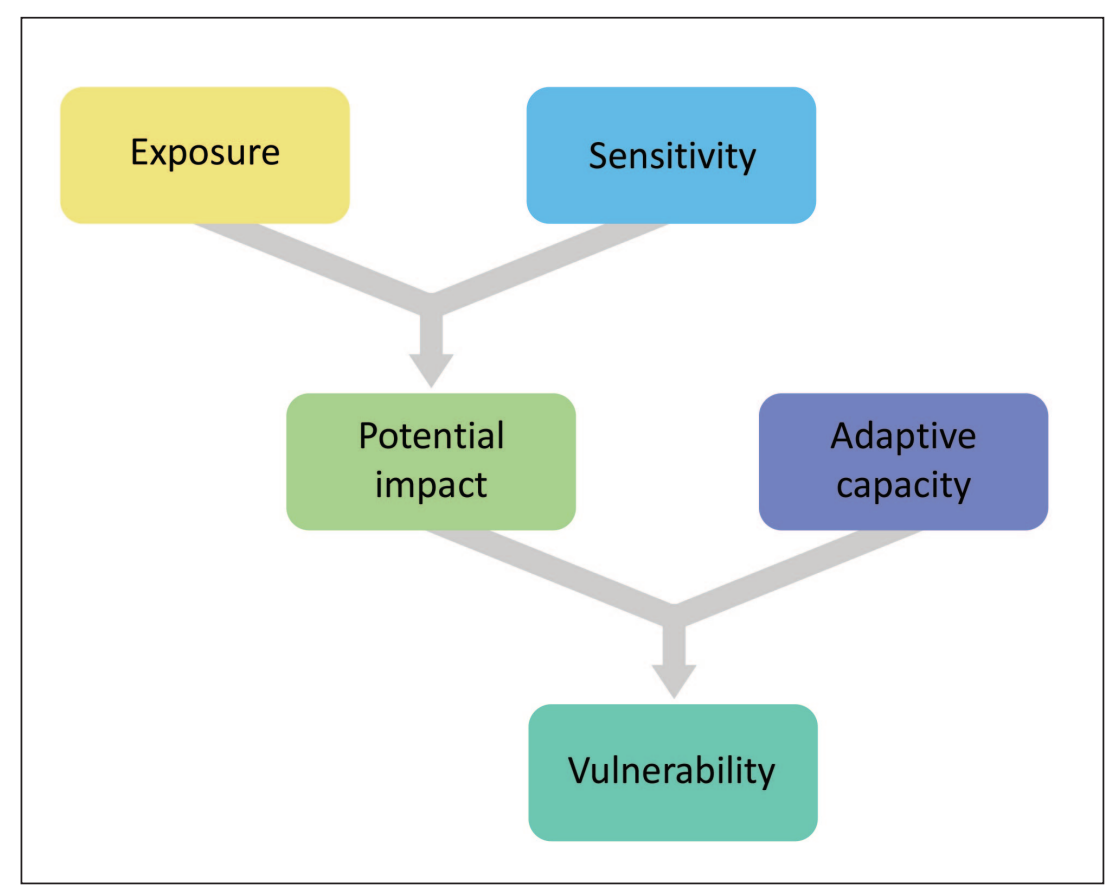

Fig. 1 The vulnerability of forests to climate change encompasses three main components: 1) the degree of tree exposure to these changes (e.g., drought, fire); 2) the sensitivity of tree species to these various stress factors; and, 3) the capacity of species to adapt to the new conditions created. Together, exposure and sensitivity define the potential impact which, combined with adaptation capacity, determines forest vulnerability. Adapted from Glick et al. (2011).

the natural adaptation of species as well as a diversity of forest responses to the expected changes.

\section{Integrating new and natural dynamics in the design of adaptive silvicultural strategies}

Maintaining the structure, functions and services provided by forest ecosystems within the context of global change represents a major challenge for forest managers and decision makers. To deal with it, a range of adaptation approaches have been proposed, ranging from resistance strategies to transition strategies. Their operational effectiveness in reducing the risks associated with climate change still remains uncertain however. Despite advances in knowledge, certain approaches developed before adaptation management became a central concern, such as ecosystem-based management, have become less popular. Moreover, several operational examples of adaptation strategies to climate change and the effects of invasive species exist in northern and temperate ecosystems. Furthermore, the integration of knowledge acquired regarding natural dynamics and ecological processes within the context of ecosystem-based management is advantageous. Even if, ultimately, new dynamics become more likely dominant, the understanding of natural dynamics remains a logical starting point for guiding choices in regeneration methods, structural attribute conditions, species and functional traits to be promoted in adaptation strategies.

The choice of stems to be conserved during regeneration cuts is an important consideration in adaptation forestry strategies (Ontl et al. 2018). In most cases, adaptive silvicul- ture aims primarily to promote species that are adapted to the future conditions predicted in climate projections. However, emulating historic disturbance regimes to promote these species remains a valid approach. For example, the majority of species described as "adapted to the future climate" in the northern hardwood forests in US states around the Great Lakes and in the US Northeast are classified as intolerant or semi-intolerant to shade (Fig. 3; Handler et al. 2014; Janowiak et al. 2018). In contrast, species that are shade tolerant, namely sugar maple (Acer saccharum Marsh.), perform well in silvicultural systems using selective cutting, which often excludes species that are less tolerant (Webster and Jensen 2007). In the past, intermediate disturbances such as windfall caused by windstorms have been shown to be essential in the creation of recruitment conditions necessary to species that are tolerant and semi-tolerant to shade in these ecosystems. Emulating these natural dynamic patterns through irregular progressive cutting provides an opportunity to naturally recruit species adapted to the future, if they are present, or to provide adequate conditions for enrichment plantings focused on improving future functional response (see Messier et al. 2019).

\section{Forêt s'Adapter: a research program for the devel-} opment of silviculture adapted to climate change The purpose of the applied research program Forêt s'Adapter, developed in partnership with private woodlot stakeholders in Montérégie and Bellechasse (Quebec), is to acquire knowledge and create tools for implementing a silvicultural system that is adapted to the threats posed by global changes. One of the first phases of the programs is to assess

\section{Adaptation to Climate Change: A Multi-faceted Concept}

The term adaptation is applicable to both biological and human systems (Gauthier et al. 2014) and can refer to various change responses. Adaptation can mean the inherent capacity of a biological or human system to adjust and adapt to the negative consequences of climate change. This adaptive capacity corresponds to the third component of vulnerability. The term adaptation can also qualify the actions taken to limit the impacts of climate change on ecosystems and forestry-based economies. This therefore involves measures, options or even adaptation strategies. Throughout this article, the term adaptation will be used alternatively in either of these contexts. 


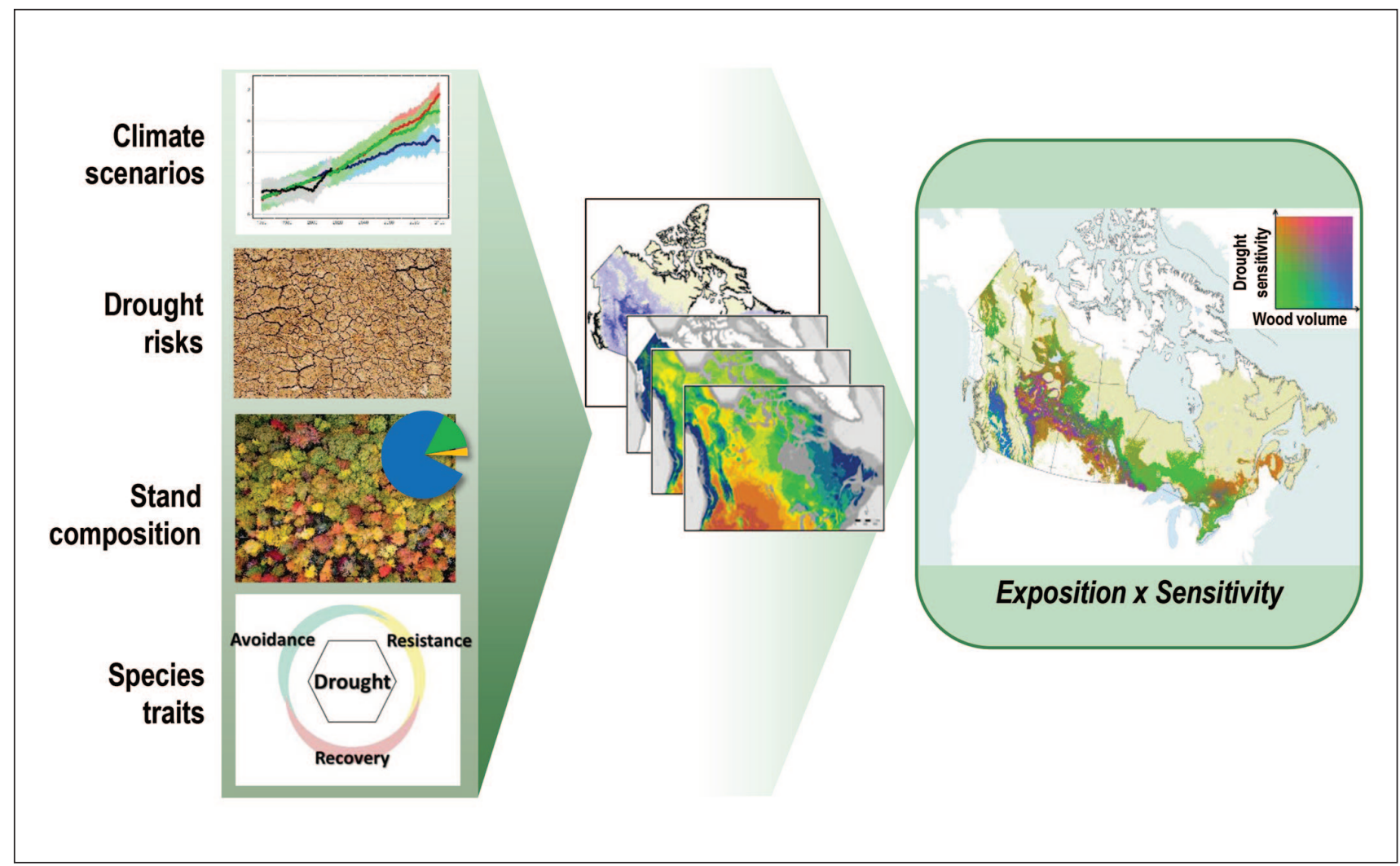

Fig. 2 Conceptual framework for an integrated evaluation of the potential impact of climate change on Canadian forests. The biophysical predictions for exposure are integrated into the ecological knowledge on tree sensitivity (traits of species) and the composition of stands in order to produce maps of areas where the forest biomass is exposed and sensitive to the stress factors associated with climate change.

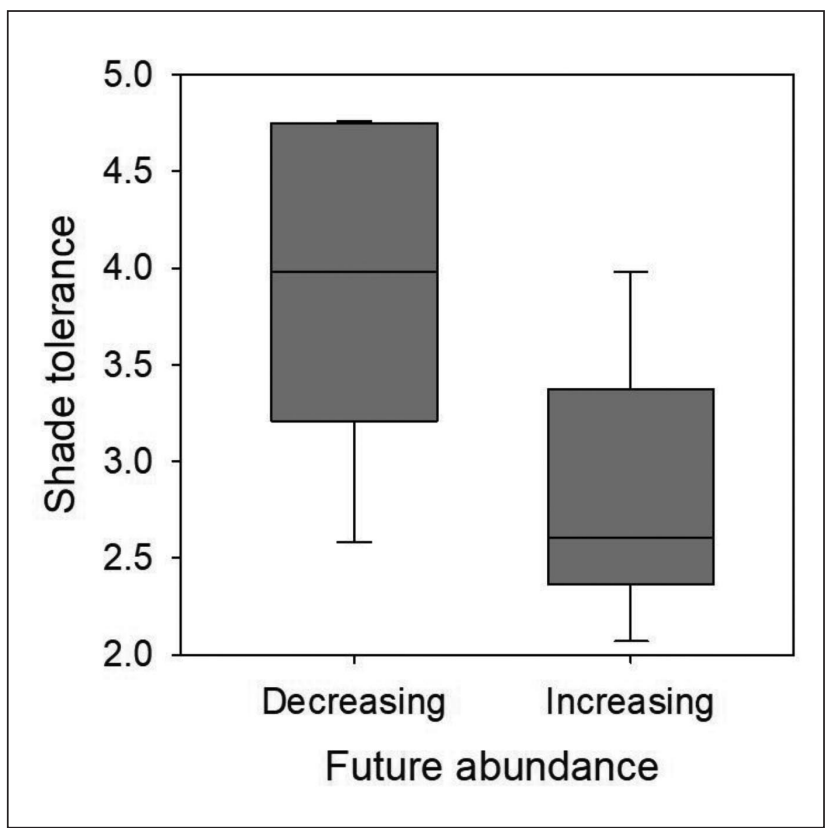

Fig. 3 Value of shade tolerance in species that, based on projections, will see a decrease or increase in future abundance over the next 100 years in Northern New England, within the context of a high-emission scenario based on Prasad et al. (2007).

Shade tolerance values for species range from 1 (very intolerant) to 5 (very tolerant) and are based on the classification by Niinemets and Valladares (2006). the vulnerability of forest ecosystems and the sensitivity of various tree species to global change threats by identifying the exposure factors (Fig. 4a). This makes it possible to differentiate the impacts based on their probability of occurrence, their specificity (e.g., the emerald ash borer only attacks Fraxinus spp.; Fig. 4b) and their severity (loss of ecosystem services) and to map them (Fig. 5). Based on this information, an adaptation strategy is developed and used to sort stands into four classes, so as to optimize adaptation efforts (Fig. 6). This sorting is based on risk significance and the adaptive capacity of the stands. Therefore, for stands presenting a moderate risk and a high adaptive capacity, no specific adaptation measures will be applied since it is believed that they will be able to adapt by themselves to the most threatening global changes in the region. Conventional silviculture would still be applicable in such cases. Similarly, no adaptation measures are recommended for stands presenting a high risk and a low adaptive capacity; investment in costly adaptation treatments is deemed to be futile, given the little biological material in place to contend with current and future regional threats. This abandonment strategy focuses on the possibility that forest communities will be able to reorganize themselves into new better-adapted entities. For forests finding themselves in this adaptation class, but which have a high socio-economic value, a transformation strategy (sensu Millar et al. 2007) can be put in place to accelerate the reorganization of a better-adapted entity. Adaptation efforts are made in the two other classes: for stands presenting a 
a

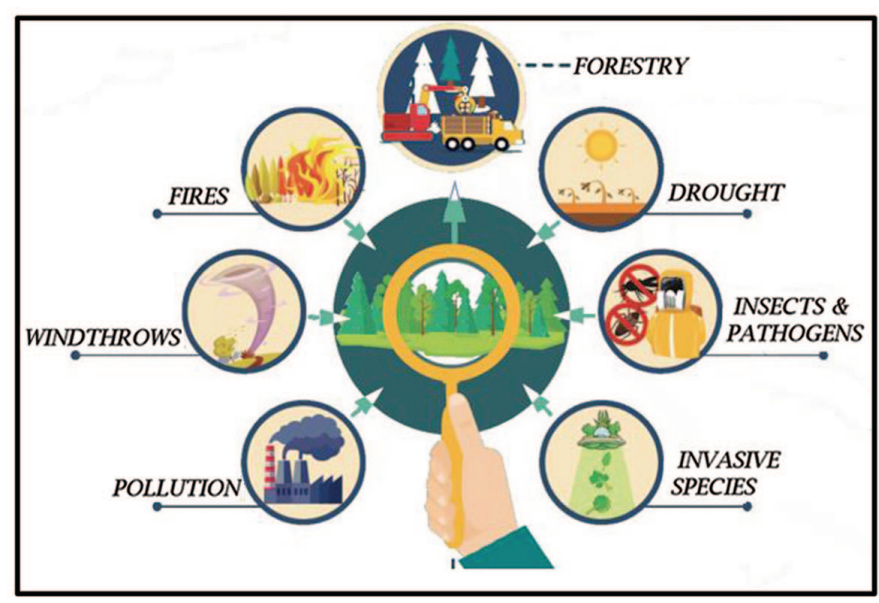

b

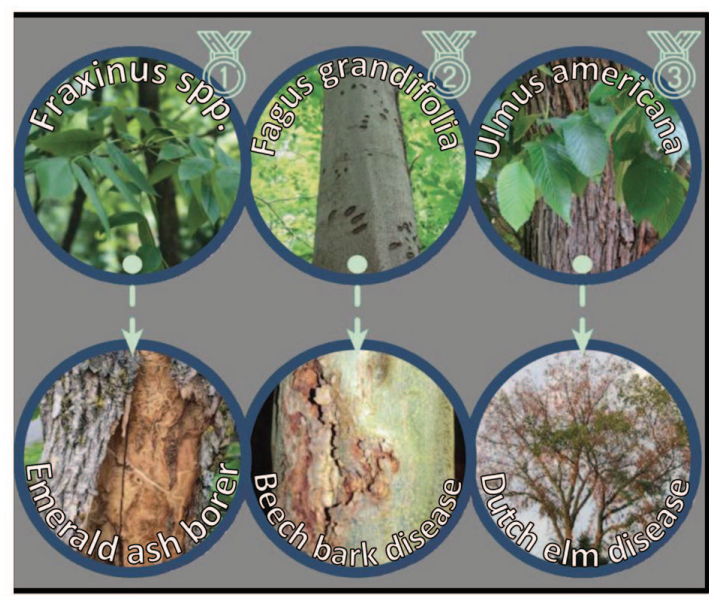

Fig. 4 Regional assessment (a) of the exposure and (b) the sensitivity of threats to global changes (images: Rita Sousa-Silva).

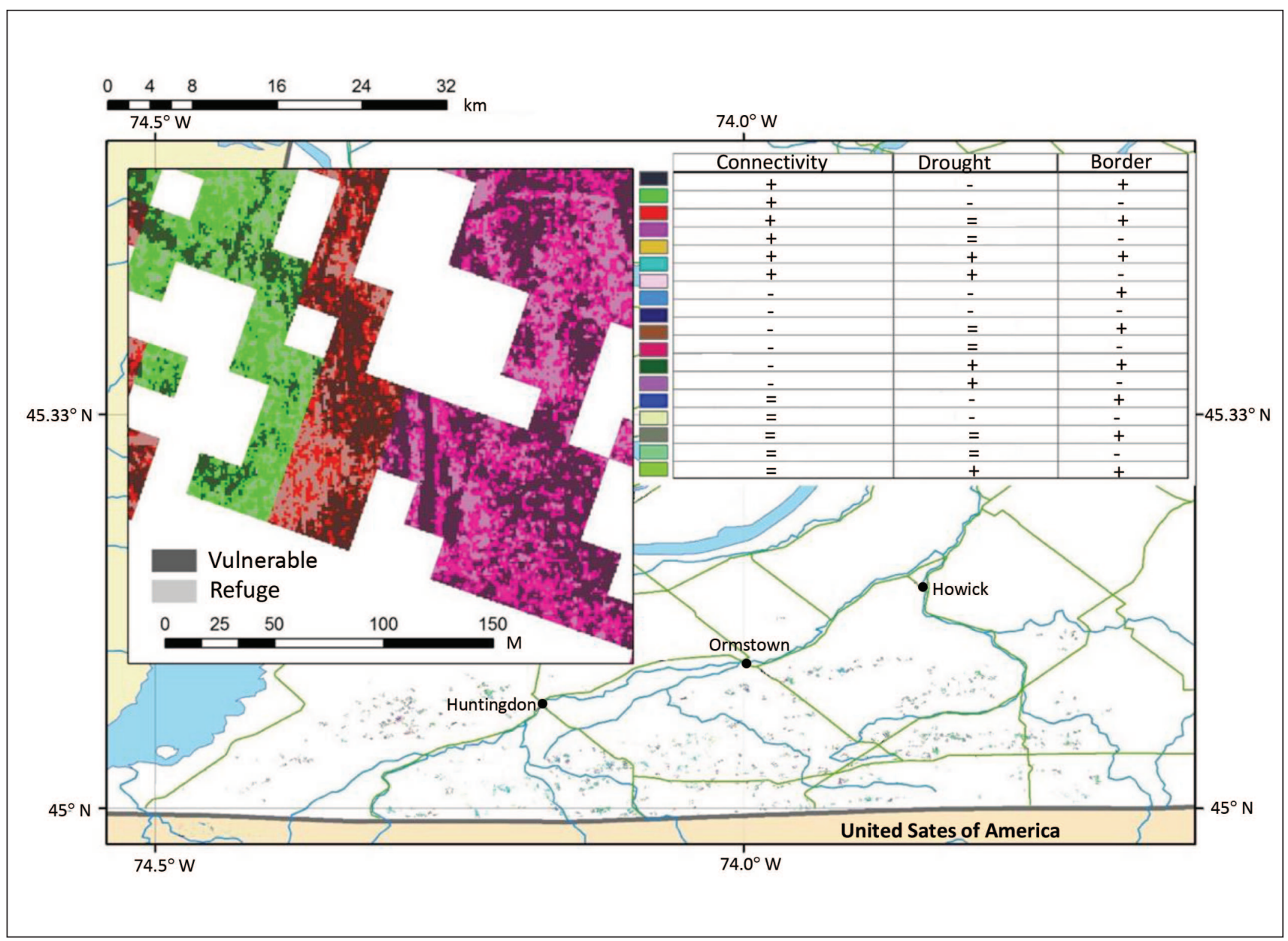

Fig. 5 Vulnerability of stands in the Vallée-du-Haut-Saint-Laurent region (Quebec). The vulnerability index takes into account fragmentation, the edge effect and an array of physiographic variables (microrelief, soil, etc.) to estimate the risks associated with white-tailed deer grazing, invasions by exotic and invasive species as well as drought. 


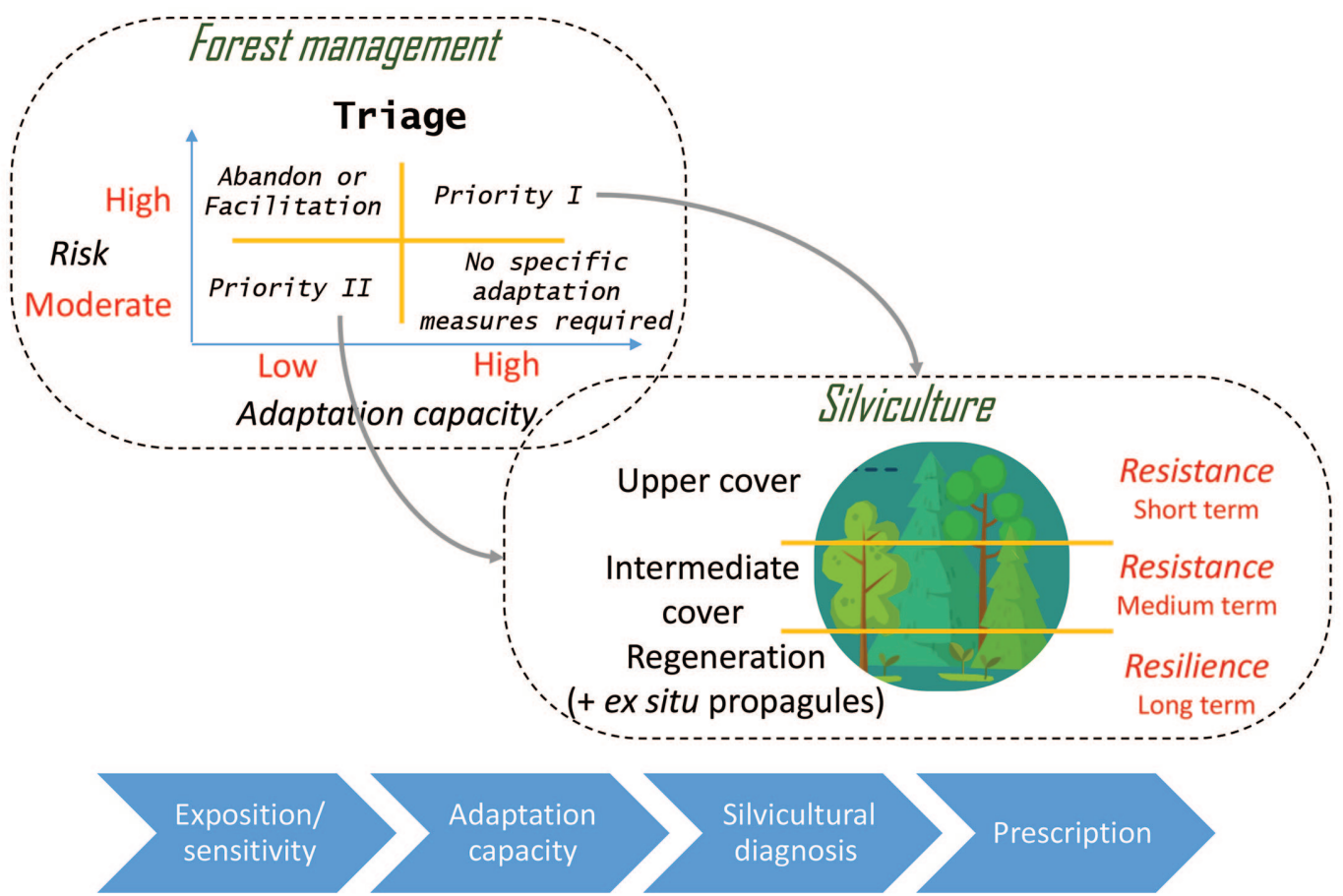

Fig. 6 The adaptation strategy based on a sorting matrix taking into account the threats associated with global changes and the adaptive capacity of stands makes it possible to optimize intervention priorities.

high risk and high adaptive capacity and to those presenting a moderate risk and low adaptive capacity (Fig. 6). For these two groups, silviculturists can work on short-term resistance with the upper cover, on mid-term resistance with intermediate cover or long-term resilience with potential regeneration (Fig. 6). The choice is made during the silvicultural diagnosis based on 1) the owner's other management objectives, and 2) the functional traits of the species present in the stand and their distribution in these three vegetation strata (dominant cover, intermediate cover and regeneration). The functional traits for this silvicultural diagnostic will be those conferring adaptive capacity to regional threats from global changes as defined in phase 1 .

In collaboration with the Agence forestière des BoisFrancs as well as the Agence de mise en valeur des forêts privées des Appalaches, this approach was made operational during the implementation of two adaptive silviculture experiments (SylvAdapt), located in Central Quebec (15 sites) and Bellechasse (12 sites). Two adaptation strategies were then compared: 1) the silvicultural diagnosis approach based on the adaptive capacity of species to regional threats, as previously illustrated, and 2) the diversity insurance policy (compositional, functional and structural). At each site, four plots of 0.25 ha were treated based on three modalities: $20 \mathrm{~m}^{2} \cdot \mathrm{ha}^{-1}$ of residual basal area (BA) for the treatment of short-term resistance (control), $12 \mathrm{~m}^{2} \cdot \mathrm{ha}^{-1}$ of residual BA for the treatment of mid-term resistance and $6 \mathrm{~m}^{2} \cdot \mathrm{ha}^{-1}$ of residual BA for the treatment of resilience (for a total of 108 plots; Fig. 7a and Fig. 7b). In each plot, all trees were mapped using mobile terrestrial LiDAR (app. 50000 trees) before and after treatment (Fig. 7c). Several research projects are being conducted based in this adaptive silviculture experiment. Certain trees are equipped with instruments to monitor sap flow in order to assess their response to treatment and drought stress as well as the water balance of the stand (Fig. 7d). Furthermore, seedlings from eight deciduous species were planted in each plot: some abundant locally (Acer rubrum L., Betula alleghaniensis Britt.), others present but less frequent (Acer saccharum Marsh., Prunus serotina Ehrh, Quercus rubra L.) and others that are absent regionally (Quercus macrocapra Michx., Carya cordiformis (Wangenh.) K. Koch, Juglans nigra L.). Their eco-physiological performance will be monitored over the years to come to compare the effects of adaptive silvicultural treatments.

\section{Silvicultural options for promoting a resilient tem- perate mixedwood forest within a context of uncer- tainty}

The balsam fir-yellow birch (Betula alleghaniensis Britt.) bioclimatic domain is composed of an ecotone where species from temperate and boreal forests coexist. Given that climate change will occur at a faster pace than the adaptation or migration capacity of species, habitat loss is expected for boreal species, particularly among conifers (Iverson et al. 2008; Périé et al. 2014). These upheavals could have an impact on the composition, structure and productivity of ecosystems (Gauthier et al. 2015). Composition changes are expected in particular in forests located in the temperate- 
a

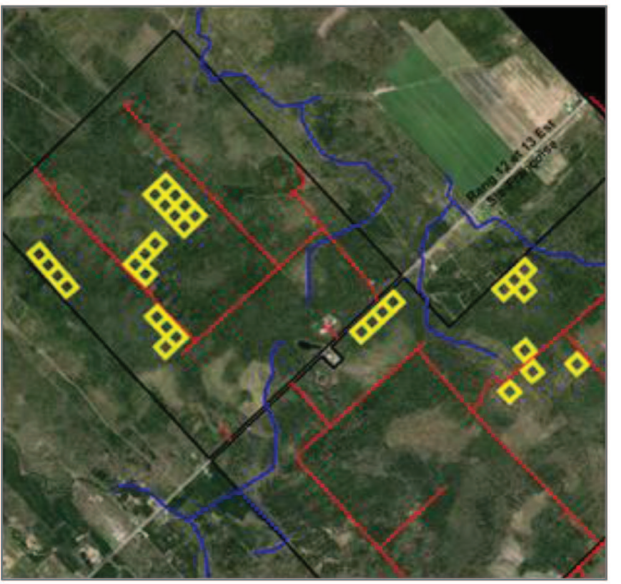

C

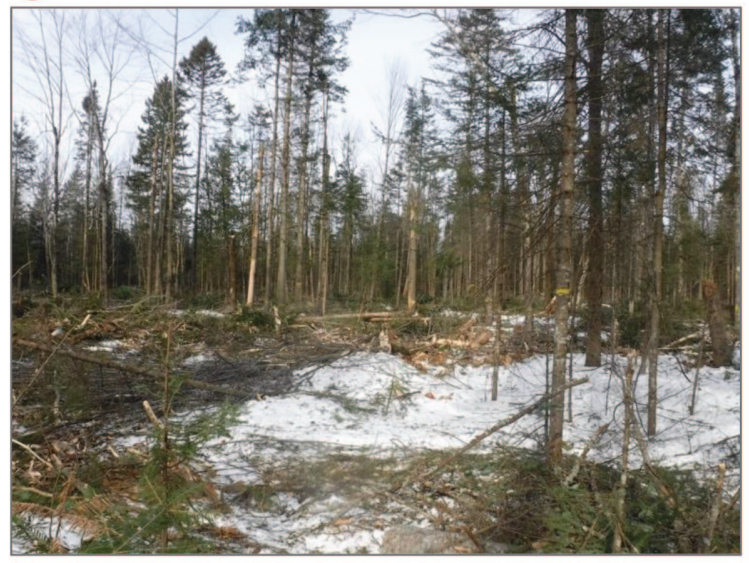

b
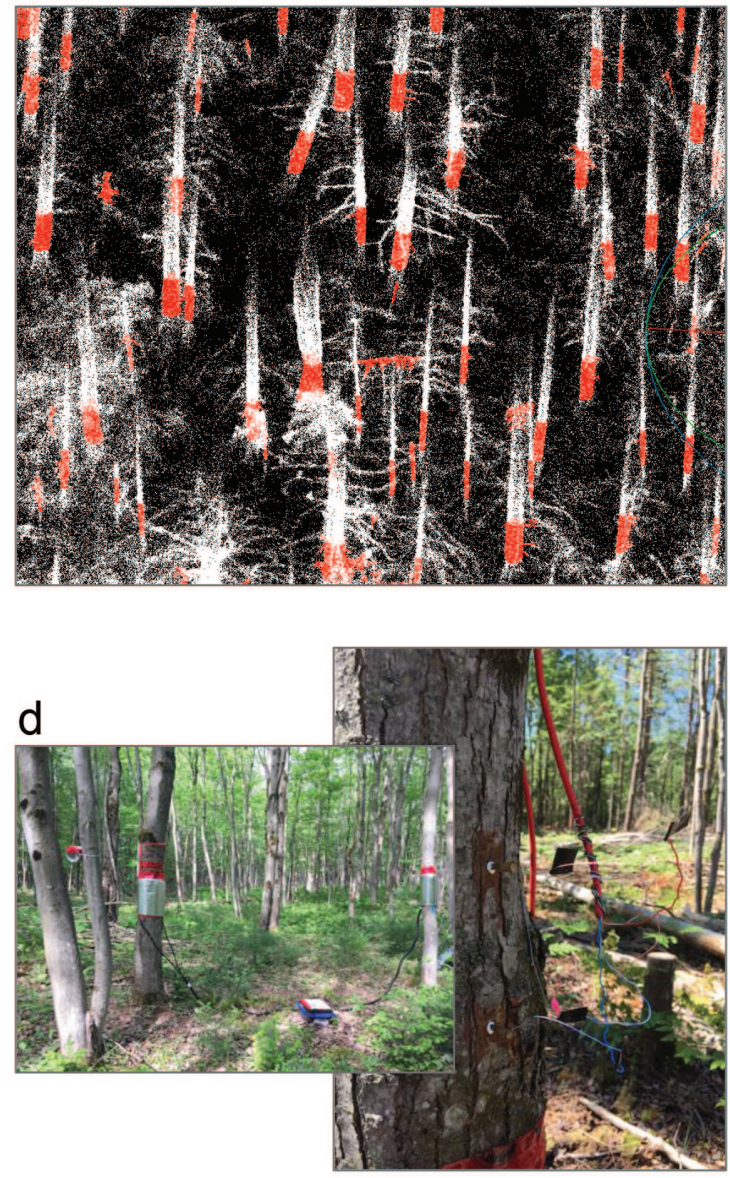

Fig. 7 The SylvAdapt experimental design of adaptive silviculture. (a) Plan of the design in Sainte-Françoise; (b) LiDAR image of part of a plot before treatment; (c) example of a plot treated for mid-term resistance using the diversity insurance policy; (d) red maples equipped with a sap flow measuring sensor (photos: Frédérik Doyon).

boreal ecotone (Reich et al. 2015). Silvicultural decisions can help forests adapt by promoting diversity and resilience as well as by facilitating the transition to new states (Millar et al. 2007). In late-successional mature and over-mature stands, the promotion of forest resistance and resilience is sought by focusing on the conservation of vigorous trees, seed bearers from declining species and the characteristics of old forests. Regeneration methods, inspired from the dynamics of natural disturbances, such as selection cutting or the irregular shelterwood method, could help in achieving this goal (Raymond and Bédard 2017; Raymond et al. 2018). Stands of intermediate age include those established after a major natural disturbance (fire, insect epidemic or windfall) or anthropic disturbance (cutting). Resistance and resilience could be improved by promoting species diversity and structural complexity (Puettmann and Messier 2019). Maintaining the coniferous component and establishing more than one regeneration cohort over time, using the shelterwood system (irregular or regular) could help in attaining these objectives (Raymond et al. 2009; Prévost and DeBlois 2014). Given that stands in the regeneration phase will suffer the effects of climate change during most of their lifespan, it would be wise to also plan for transition options. Silvicultural treatments encouraging diversity and adaptability could help mitigate the effects of climate changes on young stands. Tree selection during silvicultural treatment will help reduce the vulnerability of these stands in the future. The use of mixedwood pre-commercial thinning and mixed plantations could be wise choices in promoting functional diversity and maximizing adaptability. Preference will be given to the selection of vigorous trees, drought-tolerant species or from sources compatible with the future climate. Lastly, the assisted migration of species and genotypes will more than likely be part of the strategies for climate change adaptation (Ste-Marie et al. 2011). Research is ongoing to find out more about the conditions for the success of these plantations in order to integrate them into forestry planning (Fig. 8).

\section{Issues and opportunities for adaptive silviculture in boreal forests}

Boreal forests are biomes that are particularly sensitive to climate change (Gauthier et al. 2015). A hotter and dryer cli- 


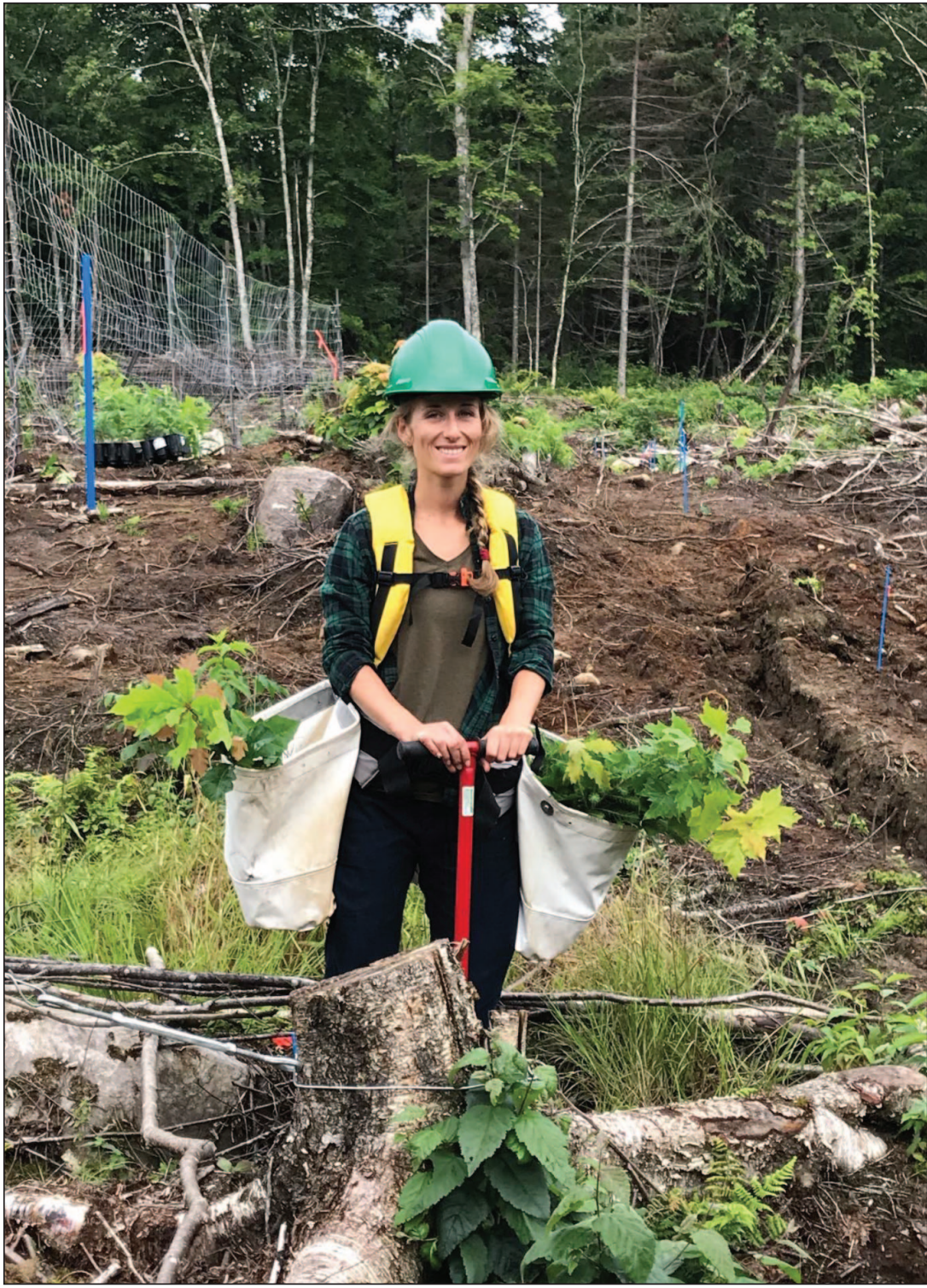

Fig. 8 MFFP's Direction de la recherche forestière putting in place an experiment to test silvicultural scenarios integrating assisted migration in mixedwood forests (photo: Patricia Raymond].

mate will ultimately lead to reduced productivity and increased mortality (D'Orangeville et al. 2018). These changes will occur faster than the speed at which species can adapt; they could also result in ecosystem simplification (Brandt et al. 2013). Climate change will also impact the disturbance regime and could compromise the capacity of boreal forests to regenerate, which raises many issues (Fig. 9). Specifically, the physiological stress associated with changes to the precipitation regime is likely to cause increased mortalities in forest regeneration.

Adaptive silviculture could help mitigate the effects of climate change in boreal forests by promoting resistance, resilience or even the transition of boreal ecosystems, particularly at the regeneration stage. Black spruce (Picea mariana (Mill.) (B.S.P.) will be among the commercial species most affected by rising temperatures and water deficits (Boucher $e t$ al. 2020). Given the importance of this species in boreal forest cover, low survival rates could cause an increase in regenera- tion failures. Ongoing research will make it possible to understand its response to water stress, particularly to cavitation (the formation of air bubbles in the water column) (Fig. 10). Innovative silvicultural practices, such as the planting of nurse plant species in addition to mechanical soil preparation, have demonstrated the potential for stimulating the growth of trees planted in boreal regions where growing conditions are limiting (Thiffault and Hébert 2017; Urli et al. 2020). The mixed plantation of species that are less sensitive to drought extremes could limit the loss of productivity. Climate change has the potential of changing the phenology and distribution of competing species (Fridley 2012). Vegetation management practices will need to be adapted, namely to take into account the northern expansion of invasive exotic species such as glossy buckthorn (Frangula alnus Mill.) (Labonté et al. 2020).

\section{Adapted forestry in the transition zone: the case of the Lake Dupar- quet Research and Teaching For- est Research Station (FERLD)}

Important to Quebec economically and ecologically, the boreal mixedwood forest is a transition zone between temperate forests, dominated by deciduous species, and coniferous boreal forests. The natural dynamics in this forest zone are mainly controlled by forest fires and insect epidemics (i.e., spruce budworm and forest tent caterpillar; Morin et al. 1993; Bergeron 2000). In the Abitibi region, the mixedwood sites in this forest zone are typically dominated by trembling aspen (Populus tremuloides Michx.) or jack pine (Pinus banksiana Lamb.) in early succession, then by fir (Abies balsamea (L.) Mill.) and cedar (Thuya occidentalis L.) in late succession. Moreover, certain species typical of hardwood forests, e.g., sugar maple, yellow birch, white pine (Pinus strobus L.) and red pine (Pinus resinosa Ait.), reach the northern boundary of their distribution range, whereas other might establish, e.g. basswood (Tilia americana $\mathrm{L}$.) and red oak. Within this context, any changes to the disturbance regime could promote the dispersion and establishment of some of these marginal species, particularly those adapted to a disturbance regime that includes various degrees of severity (Frelich 2002). Since the expected climate change is likely to modify the disturbance regime in boreal mixedwood forests, these changes could also lead to changes in the stand composition and further alter the disturbance regime to enable the sustainable establishment of marginal species (Flannigan et al. 2000). In order to take into account these potential modifications in forest composition, the development of new silvicultural scenarios (e.g., irregular shelterwood, thinning or soil amendments) or the selection 


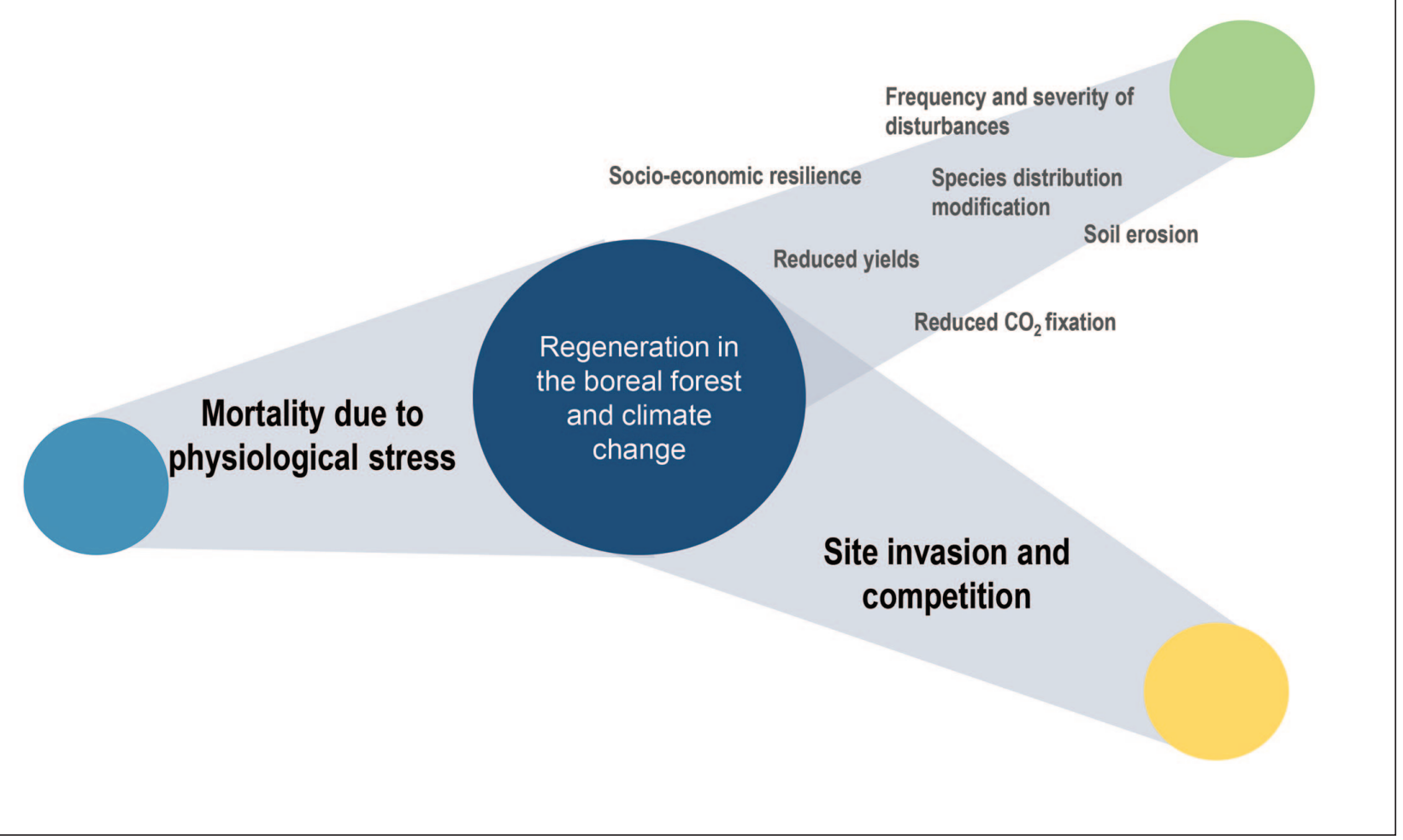

Fig. 9 Some issues associated with climate change in terms of regeneration and maintenance of boreal forest productivity.

of genotypes could be necessary. The FERLD is a laboratory where these approaches could be tested.

\section{Contribution of forest genetics to reforestation: past, present and future}

Forest genetics make it possible to decipher differences between the individuals of a same species in relation to natural genetic variability. Although not very well known by the public, this knowledge is now being integrated into tree improvement and the production of seeds and seedlings in Quebec (Perron et al. 2020). Starting in the 1950s, provenance tests were established for various native species. These made it possible to determine improvement zones and to choose the highest-performing provenances that were the best adapted to conditions at the reforestation site. Moreover, several progeny tests made it possible to estimate the improvement value of hundreds of thousands of possible parents for selection based on productivity and wood quality. Today in Quebec, 85\% of the seedlings used for reforestation come from genetic improvement programs. More recently, the results from progeny tests were used to develop transfer models (e.g., Rainville et al. 2014) in order to optimize local adaptation to climate change based on territories of use that are dynamic, i.e., that take into account that populations could become maladapted to their local climate (Fig. 11). Genomic selection is progressively being integrated for spruce, e.g., Norway spruce (Picea abies (L.) Karst.) (Lenz et al. 2020). Genomics make it possible to confirm that climate adaptation is the result of a multitude of genes with small effects and that multiple regions of the genome are involved in the bud break, growth and hardening processes (Pavy et al. 2017). Dendrochronological analyses of many white spruce progeny and provenances also resulted in the discovery of an important genetic variation for resistance to water stress (Depardieu et al. 2020). Soon, genetic improvement will progressively integrate multi-criteria selection assisted by genomics. This way, characteristics that are difficult to measure and important for adaptation will be further taken into consideration (Perron et al. 2020). There are also plans to use multisite testing over large climatic gradients to adapt the transfer models and better detect genetic variations linked to adaptation, which to date have been difficult to find. Consequently, this will help maintain the productivity and resilience of planted trees. Together, these approaches will speed up the acquisition of knowledge on the characteristics associated with adaptation, to support forest renewal within the context of climate change.

\section{The challenges of implementing assisted migration} proposed as an adaptation measure to climate change For reforestation in Quebec, each seed source (provenance) is associated to a specific territory of use where the seedlings are deployed. The underlying principle is that a local source is the best adapted. However, climate change is now challenging that principle. Assisted migration consists of moving species or populations to habitats where future climate conditions could be more favourable (Fig. 12). In Quebec, this movement is generally from south to north. Assisted migration thereby represents a silvicultural option for maintaining the productivity and resilience of planted trees. However, 


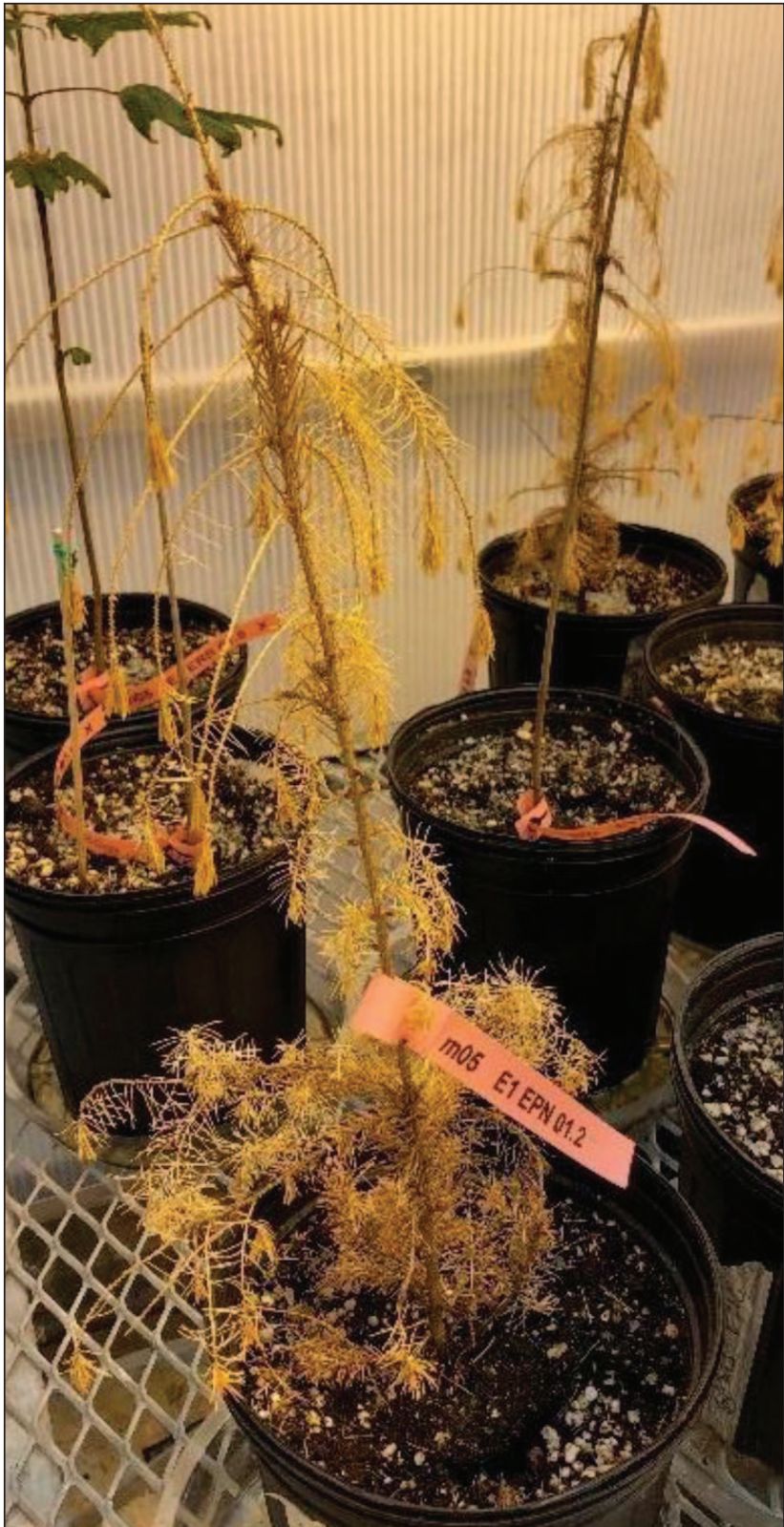

Fig. 10 Black spruce seedlings in a greenhouse experiment at Université Laval. The objective of this study, in collaboration with Morgane Urli (Université Laval), Alison Munson (Université Laval), Marie Coyea (Université Laval), Catherine Périé (Ministère des Forêts, de la Faune et des Parcs du Québec] and Nelson Thiffault (Natural Resources Canada), is to compare the physiological responses and drought vulnerability of five temperate northern and boreal species subjected to different climate conditions (photo: Nelson Thiffault)

seedlings planted today must survive under current climate conditions before being able to perform under future conditions; the implementation of assisted migration must therefore also take into account the risk of maladaptation at the juvenile stage, which increases with the translocation distance.
The assisted migration currently planned in Quebec consists of moving populations within the distribution range of a species in order to minimize genetic maladaptation in the future, without compromising their survival during the first few years after being planted (Ste-Marie et al. 2011). Its implementation for white spruce is in progress and has translated in the updating of the territories of use modelled for an average climate in 2050.

In cases where assisted migration would be used to introduce species into regions where they are not currently present (assisted range expansion; Ste-Marie et al. 2011), but where expected climate conditions will become favourable in the future, several other questions still need to be answered. Biophysical limitations, namely soil fertility, need to be considered when planning such moves. Assisted migration, a promising tool in the adaptation of plantations to climate change, still needs to be deployed with caution and by integrating new knowledge as it becomes available (Aubin et al. 2011).

\section{Challenges of implementing adaptation strategies: point of view of forest managers}

The resilience of hardwood and mixedwood forests is at the heart of current concerns regarding the announced changes. The connectivity of large forests and the complexity of stands, both in terms of their structure and composition, are key elements that could help forests adapt to present and future changes. Other elements such as the modification of precipitation and fire regimes or even human disturbances must be included in these considerations. As practitioners, are foresters not already overwhelmed by this phenomenon? A reflection on their actual capacity for intervention is required.

The effervescence created in 2013 during the implementation of the new forestry regime in Quebec tested the adaptation capacity of forest professionals. The multitude of issues to reconcile, the need to consider the economic, social, environmental and organizational contexts in order to get positioned and the accelerated acquisition of knowledge quickly become dizzying to many. The challenges that presented themselves then made it possible to see the scope of those stemming from the need to adapt to the context of climate change. Will forest stakeholders be able to deploy their adaptive capacity in order to monitor them? Will the winning conditions be there?

\section{Summary: perceptions, risks and opportunities associated with climate change}

It is clear that perceptions regarding the risks and opportunities of climate change weigh heavily on the development of policies and programs aimed at promoting forest adaptation and managing these changes (Williamson et al. 2005). This involves elected officials, managers, scientists and society in general. To end the symposium, as a form of summary, the participants took part in an introspection exercise to provide an overview of their perceptions regarding the risks and opportunities for the Quebec forestry sector over the next hundred years. In an interactive manner, a series of open and closed questions were asked to the audience to draw up a list and estimate the scope of the perceived risks and opportuni- 


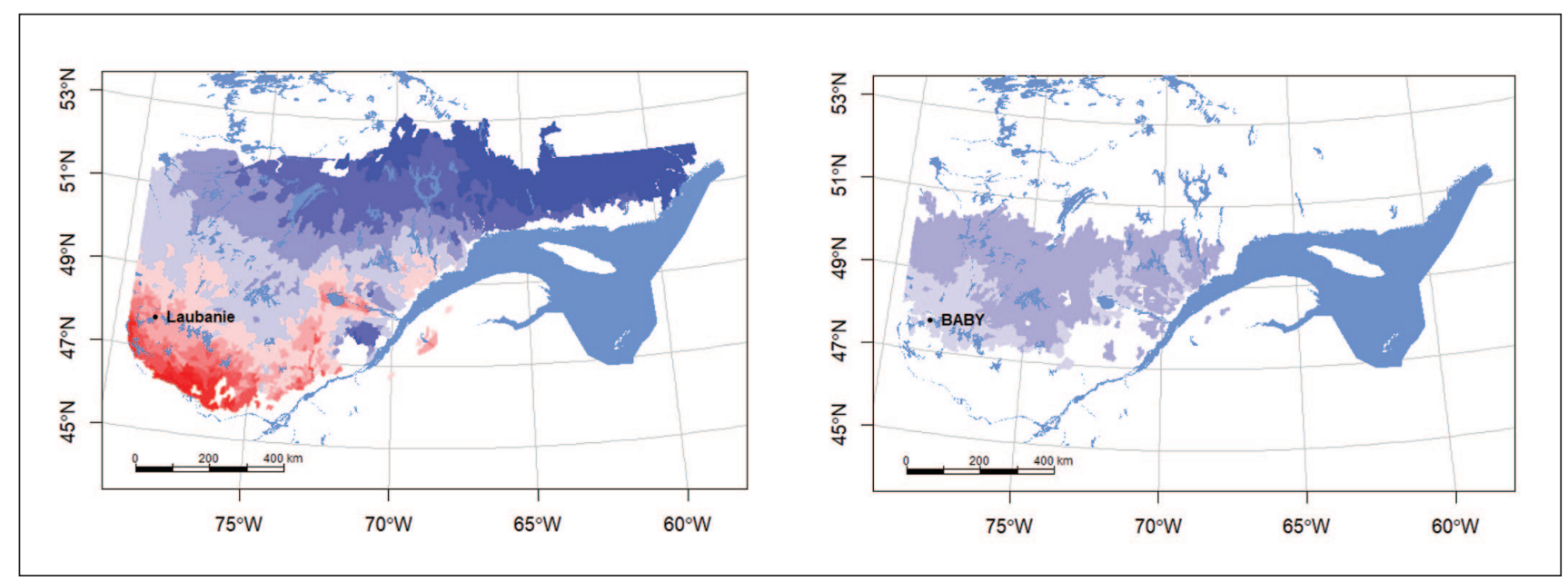

Fig. 11 Examples of simulated differences in merchantable volume based on the climate variables for dynamic use territories for black spruce (left) and white spruce (right). The colour scale goes from blue (gain in merchantable volume) to red (loss in merchantable volume). Transfer model: Rainville et al. (2014); simulations: M.-C. Lambert, MFFP.

ties and to list the potential solutions. The app Web Mentimeter ${ }^{3}$ was used to collect the responses of participants using their smartphones and to discuss the results in real time.

Forty-four people participated in the survey. Most of the respondents were from the government sector $(54 \%)$, academia $(35 \%)$, teaching and research $(57 \%)$ or planning (29\%). These professionals work on boreal forests (25\%), mixedwood forests (41\%) and hardwood forests (34\%).

Based on the proposed list (Fig. 13a), the participants ranked drought at the top of the list of risks and issues in terms of climate change; this was followed by the limited migration capacity of trees and the problem of invasive species. Political will, social acceptability and the implementation of adaptation strategies were among the issues added to the list by participants, along with the changes in operational conditions during the winter months and the technological capacity to deal with changes. The associated risk was deemed very high by most of the participants, with a likelihood deemed high and an impact deemed to be significant (Fig. 13b)

All changes were associated with risks but also with opportunities. Climate being one of the main factors limiting forestry production, there is room, for example, to wonder about the possible advantages of a different climate on the growth of trees. Among the opportunities perceived by participants, there was the establishment and silviculture of new species, associated with a possible increase in biodiversity. This could lead to the development of new markets and products, namely in the emerging green economy. The response of forests to climate change could also increase the contribution of forests to the management of greenhouse gas emissions and improve the forestry sector's position in public opinion. Several participants emphasized that this was an opportunity to review and improve forestry management practices. The perceived level of opportunity, combining the probability and importance of the impact, varied greatly among the participants, with a central trend in favour of a high level of opportunity (Fig. 13c).

\footnotetext{
${ }^{3}$ www.mentimeter.com
}

Several presentations at the symposium proposed adaptation measures for forest management. The participants were asked to rate the relevance of the elements from a list of proposed solutions (Fig. 13d). Regeneration and mixed stand management, namely through assisted migration enrichment plantings, were at the top of the list. Among the additional solutions proposed by the participants, several mentioned a reduction in rotation periods for reducing exposure to risk over time and the progressive adaptation of stand composition to the climate, using fast-growing species, fertilization and irrigation. Involving the experience and knowledge of Indigenous peoples and expanding rotations to increase $\mathrm{CO}_{2}$ capture were also mentioned.

The exercise made it possible to provide an overview of the perceptions and priorities of the forestry researchers and professionals present at the symposium. The elements presented intersected the observations from rigorous studies conducted recently (Capstick et al. 2015; Morin et al. 2015; Bissonnette et al. 2017; Ameztegui et al. 2018).

\section{Conclusion}

The symposium Adaptive Silviculture for Climate Change: From Concepts to Reality made it possible to understand the effects of anticipated global changes on the physiological and ecological processes that determine forest dynamics, as well as their anticipated effects on the production of ecosystem services. The symposium contributed directly to the effort of transferring knowledge to silviculturists, namely by presenting silvicultural practices and implementation conditions that encourage the adaptation of forests to climate change. The invited speakers addressed the issue of adaptive silviculture, first by explaining the theoretical concepts, then by proposing concrete solutions that are well anchored in reality. They provided information on the various adaptation sensitivities and capacities of tree species, important information for better understanding the vulnerability of Quebec forests to climate change. The participants then reflected on the place of ecosystem management in adaptation strategies, namely on the principle of an array of adaptation approaches (resistance, resilience and transition) using adaptation sce- 


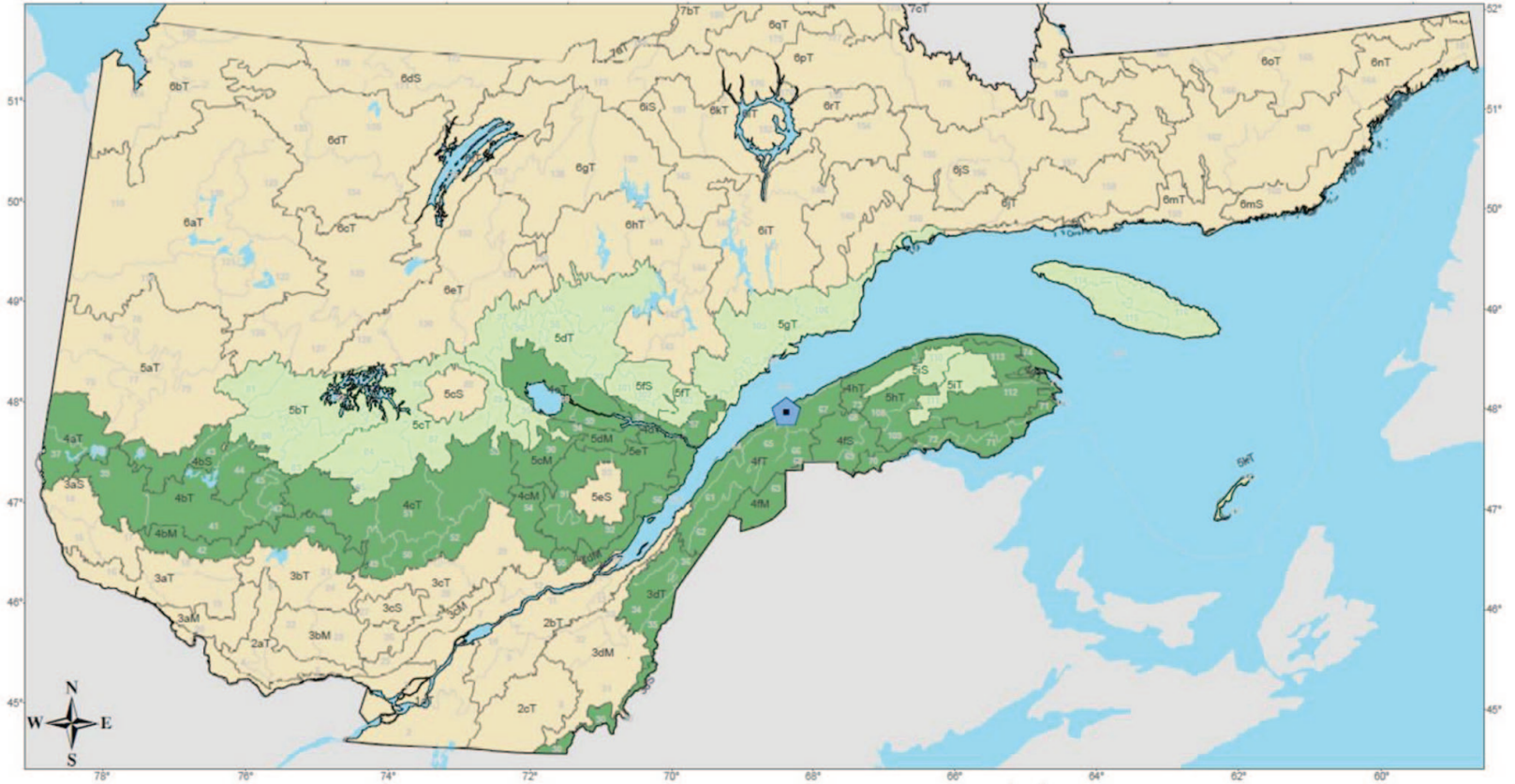

Fig. 12 By using measurements taken at nine test plantation sites along three south-north transects representing a climatic gradient of $5.8^{\circ} \mathrm{C}$ in Quebec (Lamhamedi et al. 2017), it was possible to update the territory of use for the $2^{\text {nd }}$ generation white spruce seed orchard in Sainte-Luce (dark green), expanding it to the north and east (light green) (Benomar et al. 2018).

narios that were experimented on in the US, in northern hardwood stands of New Hampshire. Then the most recent knowledge from the Forêt S'Adapter research project was presented regarding the hardwood forests in Southwest Quebec, a program that revolves around the concepts of resistance, resilience and transition. The symposium then addressed topics that were a bit more practical with a series of presentations on examples of silvicultural treatment that can be applied within an adaptation context. Presentations were given on adaptation options based on the stand developmental stage for temperate mixedwood forests, examples from boreal forests and options for boreal mixedwood forests, using the FERLD example. These presentations illustrated how the concepts of adaptive silviculture targeting the resistance, resilience or transition of stands apply to various bioclimatic realities in Quebec.

In the afternoon, a session of presentations addressed a wide variety of issues associated with adaptive silviculture, ranging from the physiology of plants and browse resistance to diagnostic and silvicultural prescriptions ${ }^{4}$. The symposium then explored how progress in genetic improvement can contribute to the implementation of transition strategies, e.g. assisted migration. There was then an exploration of the challenges presented by the implementation of such strategies, namely in terms of the choice of species and provenances for the production of seedlings compatible with the future climate. Afterwards, two experienced forestry engineers shared

\footnotetext{
${ }^{4}$ The presentations are available here:

https://mffp.gouv.qc.ca/documents/forets/recherche/Actes_Carrefour_Forets_2019.pdf
}

their ideas regarding adaptive silviculture and its integration into practice, taking into account organizational and human factors. More specifically, they listed the challenges of adaptation in practice and initiated a call for collaboration. They highlighted the fact that the complexity of the forest management process requires better communication between the research field and the professional field, one of the challenges addressed at this symposium.

We hope that the exchange of knowledge and the reflections of participants as well as the summary of the perceived risks, possibilities and solutions will help the forestry sector put in place the policies and measures for climate change adaptation for the forest management of the $21^{\text {st }}$ century.

\section{Acknowledgements}

We want to thank the organizing committee for the Carrefour Forêts 2019 that permitted and facilitated the holding of this symposium. In particular we want to thank Marie-Ëve Roy, Luciana Perecin and Hélène Labbé (MFFP), who contributed directly to the success of this activity. We also want to thank the co-authors of the presentations as well as the participants in the flash-talk session: Donald Blouin (CERFO), Émilie Champagne (MFFP-DRF), Caroline Gagné (UQAM), Jérôme Laganière (NRCan-CFS), Miguel Montoro Girona (Swedish Agricultural University, UQAC), Sergio Rossi (UQAC), Samuel Roy Proulx (UQAT), Rita SousaSilva (ISFORT, UQO) and Mariétou Diouf (UL-CEF, MFFP) and their co-authors. Lastly, we want to thank Edouard Thiffault for translating some sections of the original text, and Denise Tousignant (MFFP) for editing the entire original manuscript (in French). 
a

Perceived level of importance of issues

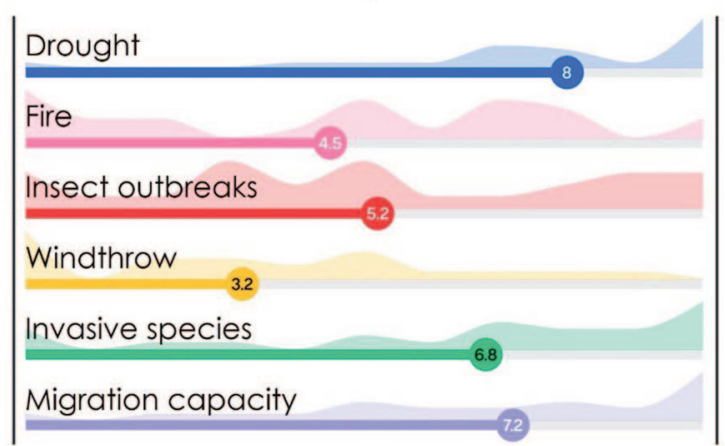

b

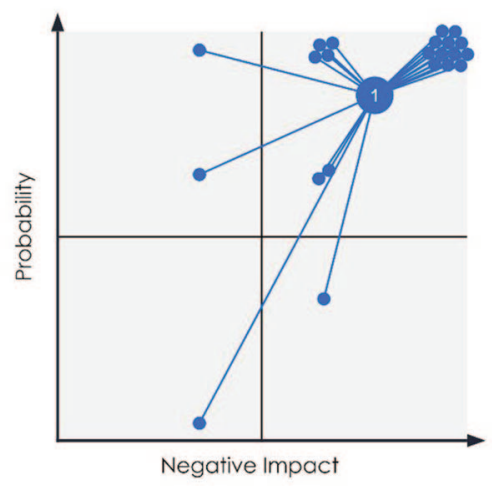

C

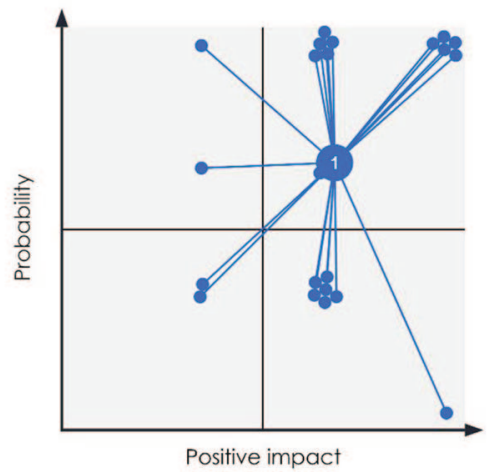

d

Perceived level of relevance of solutions

Fig. 13 Summary of the symposium participants' perception of the risks and opportunities associated with climate change for the Quebec forestry sector over the next century. Chart (a) presents the breakdown in the level of importance (from $1=$ low to $10=$ high) allocated to a list of issues. Chart (b) is the risk matrix in which the participants rated both the impact and likelihood of the listed risks. Chart (c) presents the level of opportunity perceived for the various possibilities, both in terms of their impact and their likelihood. Chart (d) illustrates the level of relevance perceived for a few of the solutions presented during the symposium to adapt forest management to climate change (based on a scale of $1=$ low to $3=$ high). Charts (b) and (c) show both the central trend and dispersion of scores.

\section{References}

Allen, C.D., A.K. Macalady, H. Chenchouni, D. Bachelet, N. McDowell, M. Vennetier, T. Kitzberger, A. Rigling, D.D. Breshears, E.H. Hogg, P. Gonzalez, R. Fensham, Z. Zhang, J. Castro, N. Demidova, J.-H. Lim, G. Allard, S.W. Running, A. Semerci and N. Cobb. 2010. A global overview of drought and heat-induced tree mortality reveals emerging climate change risks for forests. For. Ecol. Manage. 259(4): 660-684. doi:10.1016/j.foreco.2009.09.001. Ameztegui, A., K.A. Solarik, J.R. Parkins, D. Houle, C. Messier and D. Gravel. 2018. Perceptions of climate change across the Canadian forest sector: The key factors of institutional and geographical environment. PLoS ONE 13(6). doi:10.1371/journal. pone.0197689.

Aubin, I., C.M. Garbe, S. Colombo, C.R. Drever, D.W. McKenney, C. Messier, J. Pedlar, M.A. Saner, L.V.M. Wellstead, R. Winder, E. Witten and C. Ste-Marie. 2011. Why we disagree about assisted migration: Ethical implications of a key debate regarding the future of Canada's forests. For. Chron. 87(6): 755-765. doi:10.5558/tfc2011-092.

Aubin, I., L. Boisvert-Marsh, H. Kebli, D. McKenney, J. Pedlar, K. Lawrence, E.H. Hogg, Y. Boulanger, S. Gauthier and C. SteMarie. 2018. Tree vulnerability to climate change: Improving expo- sure-based assessments using traits as indicators of sensitivity. Ecosphere 9(2): e02108. doi:10.1002/ecs2.2108.

Benomar, L., J. Beaulieu, M.S. Lamhamedi, A. Rainville and M.C. Lambert. 2018. Migration assistée : utilisation de données écophysiologiques pour redéfinir les territoires d'utilisation des semences pour les vergers de $2^{\mathrm{e}}$ génération et raffiner les modèles de transfert de semences pour les vergers de $1^{\text {re }}$ génération. Livrable 1 : Actualisation des territoires d'utilisation des vergers de deuxième génération de l'épinette blanche au Québec. Rapport de projet.

Bergeron, Y. 2000. Species and stand dynamics in the mixed woods of Quebec's southern boreal forest. Ecology 81: 1500-1516.

Bissonnette, J.F., J. Dupras, F. Doyon, C. Chion and J. Tardif. 2017. Perceptions of small private forest owner's vulnerability and adaptive capacity to environmental disturbances and climate change: Views from a heterogeneous population in southern Quebec, Canada. Small-Scale For. 16(3): 367-393. doi:10.1007/ s11842-016-9361-y.

Böcher, M. and M. Krott. 2014. The RIU model as an analytical framework for scientific knowledge transfer: The case of the "decision support system forest and climate change". Biodiv. Conserv. 23(14): 3641-3656. doi:10.1007/s10531-014-0820-5.

Bonan, G.B. 2008. Forests and climate change: Forcings, feedbacks, 
and the climate benefits of forests. Science 320(5882): 1444-1449. doi:10.1126/science.1155121.

Boucher, D., S. Gauthier, N. Thiffault, W. Marchand, M. Girardin and M. Urli. 2020. How climate change might affect tree regeneration following fire at northern latitudes: a review. New For. 51: $543-$ 571. doi:10.1007/s11056-019-09745-6.

Brandt, J.P., M.D. Flannigan, D.G. Maynard, I.D. Thompson and W.J.A. Volney. 2013. An introduction to Canada's boreal zone: ecosystem processes, health, sustainability, and environmental issues. Environ. Rev. 21(4): 207-226. doi:10.1139/er-2013-0040.

Capstick, S., L. Whitmarsh, W. Poortinga, N. Pidgeon and P. Upham. 2015. International trends in public perceptions of climate change over the past quarter century. WIREs Clim. Change 6(1): 35-61. doi:10.1002/wcc.321.

Depardieu, C., M.P. Girardin, S. Nadeau, P.R. Lenz, J. Bousquet and N. Isabel. 2020. Adaptive genetic variation to drought in a widely distributed conifer suggests a potential for increasing forest resilience in a drying climate. New Phytol. 227(2): 427-439. doi:10.1111/nph.16551.

D’Orangeville, L., D. Houle, L. Duchesne, R.P. Phillips, Y. Bergeron and D. Kneeshaw. 2018. Beneficial effects of climate warming on boreal tree growth may be transitory. Nature Comm. 9(1): 3213. doi:10.1038/s41467-018-05705-4.

Flannigan, M.D., B.J Stocks and B.M. Wotton. 2000. Climate change and forest fires. Sci. Total Environ. 262(3): 221-229. doi:10.1016/S0048-9697(00)00524-6.

Frelich, L.E. 2002. Forest Dynamics and Disturbance Regimes: Studies from Temperate Evergreen-Deciduous Forests. Cambridge University Press, Cambridge.

Fridley, J.D. 2012. Extended leaf phenology and the autumn niche in deciduous forest invasions. Nature 485(7398): 359-362. doi:10.1038/nature11056.

Gauthier, S., P. Bernier, T. Kuuluvainen, A.Z. Shvidenko and D.G. Schepaschenko. 2015. Boreal forest health and global change. Science 349(6250): 819-822. doi:10.1126/science.aaa9092.

Gauthier, S., P. Bernier, P.J. Burton, J. Edwards, K. Isaac, N. Isabel, K. Jayen, H. Le Goff and E.A. Nelson. 2014. Climate change vulnerability and adaptation in the managed Canadian boreal forest. Environ. Rev. 22: 256-285.

Glick P., B.A. Stein and N.A. Edelson. 2011. Scanning the conservation horizon: A guide to climate change vulnerability assessment. National Wildlife Federation. www.fs.usda.gov

Handler, S., M.J. Duveneck, L. Iverson, E. Peters, R.M. Scheller, K.R. Wythers, L. Brandt, P. Butler, M. Janowiak and P.D. Shannon. 2014. Minnesota forest ecosystem vulnerability assessment and synthesis: A report from the Northwoods Climate Change Response Framework project. U.S. Department of Agriculture, Forest Service, Northern Research Station. Gen. Tech. Rep. NRS-133. Newtown Square, PA.

Iverson, L.R., A.M. Prasad, S.N. Matthews and M. Peters. 2008. Estimating potential habitat for 134 eastern US tree species under six climate scenarios. For. Ecol. Manage. 254(3): 390-406.

Janowiak, M.K., A.W. D'Amato, C.W. Swanston, L. Iverson, F.R. Thompson, W.D. Dijak, S. Matthews, M.P. Peters, A. Prasad, J.S. Fraser, L.A. Brandt, P. Butler-Leopold, S.D. Handler, P.D. Shannon, D. Burbank, J. Campbell, C. Cogbill, M.J. Duveneck, M.R. Emery, N. Fisichelli, J. Foster, J. Hushaw, L. Kenefic, A. Mahaffey, T.L. Morelli, N.J. Reo, P.G. Schaberg, K.R. Simmons, A. Weiskittel, S. Wilmot, D. Hollinger, E. Lane, L. Rustad and P. Templer. 2018. New England and northern New York forest ecosystem vulnerability assessment and synthesis: A report from the New England Climate Change Response Framework project. U.S. Department of Agriculture, Forest Service, Northern Research Station. Gen. Tech. Rep. NRS-173. Newtown Square, PA.

Klenk, N., B. Adams, G. Bull, J. Innes, S. Cohen and B. Larson. 2011. Climate change adaptation and sustainable forest manage- ment: A proposed reflexive research agenda. For. Chron. 87(3): 351-357. doi:10.5558/tfc2011-025.

Labonté, J., G. Drolet, J.D. Sylvain, N. Thiffault, F. Hébert and F. Girard. 2020. Phenology-based mapping of an alien invasive species using time series of multispectral satellite data: A case-study with glossy buckthorn in Québec, Canada. Remote Sens. 12(6): 922. doi: $10.3390 /$ rs12060922.

Lamhamedi, M.S., A. Rainville, L. Benomar, I. Villeneuve, J. Beaulieu, J. Bousquet, H.A. Margolis, J. DeBlois and M.-C. Lambert. 2017. L'écophysiologie, un atout pour réussir la migration assistée de sources génétiques d'épinette blanche. Direction de la recherche forestière, Ministère des Forêts, de la Faune et des Parcs du Québec. Avis de recherche forestière n ${ }^{\circ}$ 89. Québec, QC. Available at: https://mffp.gouv.qc.ca/publications/forets/connaissances/ recherche/Lamhamedi-Mohammed/Avis89.pdf

Lemprière, T.C., W.A. Kurz, E.H. Hogg, C. Schmoll, G.J. Rampley, D. Yemshanov, D.W. McKenney, R. Gilsenan, A. Beatch, D. Blain, J.S. Bhatti and E. Krcmar. 2013. Canadian boreal forests and climate change mitigation. Environ. Rev. 21(4): 293-321. doi:10.1139/er-2013-0039.

Lenz, P.R.N., S. Nadeau, M.J. Mottet, M. Perron, N. Isabel, J. Beaulieu and J. Bousquet. 2020. Multi-trait genomic selection for weevil resistance, growth, and wood quality in Norway spruce. Evol. Appl. 13(1): 76-94. doi:10.1111/eva.12823.

Messier, C., J. Bauhus, F. Doyon, F. Maure, R. Sousa-Silva, P. Nolet, M. Mina, N. Aquilué, M.-J. Fortin and K. Puettmann. 2019. The functional complex network approach to foster forest resilience to global changes. For. Ecosyst. 6: 16. doi:10.1186/s40663019-0166-2.

Millar, C.I., N.L. Stephenson and S.L. Stephens. 2007. Change and forests of the future: Managing in the face of uncertainty. Ecol. Appl. 17(8): 2145-2151.

Ministère des Forêts de la Faune et des Parcs 2019. Actes du Carrefour Forêts 2019: Des connaissances à la création de valeur. Gouvernement du Québec, Québec, QC. Available at: https://mffp. gouv.qc.ca/documents/forets/recherche/Actes_Carrefour_Forets_2 019.pdf

Morin, H., D. Laprise and Y. Bergeron. 1993. Chronology of spruce budworm outbreaks near Lake Duparquet, Abitibi region, Quebec. Can. J. For. Res. 23(8): 1497-1506. doi:10.1139/x93-189.

Morin, M.B., D. Kneeshaw, F. Doyon, H. Le Goff, P. Bernier, V. Yelle, A. Blondlot and D. Houle. 2015. Climate change and the forest sector: Perception of principal impacts and of potential options for adaptation. For. Chron. 91(4): 395-406. doi:10.5558/tfc2015-069. Nagel, L.M., B.J. Palik, M.A. Battaglia, A.W. D'Amato, J.M. Guldin, C.W. Swanston, M.K. Janowiak, M.P. Powers, L.A. Joyce, C.I. Millar, D.L. Peterson, L.M. Ganio, C. Kirschbaum and M.R. Roske. 2017. Adaptive silviculture for climate change: A national experiment in manager-scientist partnerships to apply an adaptation framework. J. For. 115(3): 167-178. doi:10.5849/jof.16-039.

Niinemets, $\ddot{U}$. and F. Valladares. 2006. Tolerance to shade, drought, and waterlogging of temperate northern hemisphere trees and shrubs. Ecol. Monogr. 76(4): 521-547. doi:10.1890/00129615(2006)076[0521:ttsdaw]2.0.co;2.

Ontl, T.A., C. Swanston, L.A. Brandt, P.R. Butler, A.W. D’Amato, S.D. Handler, M.K. Janowiak and P.D. Shannon. 2018. Adaptation pathways: ecoregion and land ownership influences on climate adaptation decision-making in forest management. Clim. Change 146(1): 75-88. doi:10.1007/s10584-017-1983-3.

Pavy, N., M. Lamothe, B. Pelgas, F. Gagnon, I. Birol, J. Bohlmann, J. Mackay, N. Isabel and J. Bousquet. 2017. A high resolution reference genetic map positioning $8.8 \mathrm{~K}$ genes for the conifer white spruce: structural genomics implications and correspondence with physical distance. Plant J. 90: 189-203. doi:10.1111/tpj.13478 Périé, C., S. de Blois, M.-C. Lambert and N. Casajus. 2014. Effets anticipés des changements climatiques sur l'habitat des espèces 
arborescentes au Québec. Ministère des Ressources naturelles du Québec, Direction de la recherche forestière, Mémoire de recherche forestière $\mathrm{n}^{0}$ 173. 46 p. Available at: https://mffp.gouv.qc.ca/documents/forets/connaissances/recherche/Memoire173.pdf

Perron, M., P., Lenz, M., Desponts, M., M.-J., Mottet, N. Isabel, J. Beaulieu and J. Bousquet. 2020. À l'aube d'une révolution : décoder le génome des arbres pour mieux aborder l'avenir. Avis de recherche forestière $\mathrm{n}^{\circ} 133$. Gouvernement du Québec, ministère des Forêts, de la Faune et des Parcs, Direction de la recherche forestière. 2 p. Available at: https://mffp.gouv.qc.ca/documents/ forets/recherche/ARF133.pdf

Prasad, A.M., L.R. Iverson, S. Matthews and M. Peters. 2007. A Climate Change Atlas for 134 Forest Tree Species of the Eastern United States [database]. https://www.nrs.fs.fed.us/atlas/tree, Northern Research Station, USDA Forest Service, Delaware, Ohio. Prévost, M. and J. DeBlois. 2014. Shelterwood cutting to release coniferous advance growth and limit aspen sucker development in a boreal mixedwood stand. For. Ecol. Manage. 323: 148-157.

Price, D.T., R.I. Alfaro, K.J. Brown, M.D. Flannigan, R.A. Fleming, E.H. Hogg, M.P. Girardin, T. Lakusta, M. Johnston, D.W. McKenney, J.H. Pedlar, T. Stratton, R.N. Sturrock, I.D. Thompson, J.A. Trofymow and L.A. Venier. 2013. Anticipating the consequences of climate change for Canada's boreal forest ecosystems. Environ. Rev. 21(4): 322-365. doi:10.1139/er-2013-0042.

Puettmann, K.J. and C. Messier. 2019. Simple guidelines to prepare forests for global change: The dog and the frisbee. Northwest Sci. 93: 209-225.

Rainville, A., J. Beaulieu, L. Langevin, T. Logan and M.-C. Lambert. 2014. Prédire l'effet des changements climatiques sur le volume marchand des principales espèces résineuses plantées au Québec, grâce à la génétique forestière. Direction de la recherche forestière, Ministère des Forêts, de la Faune et des Parcs du Québec. Mémoire de recherche forestière $\mathrm{n}^{\circ} 174$. Québec, QC. Available at: https://mffp.gouv.qc.ca/documents/forets/connaissances/recherche /Memoire174.pdf

Raymond, P. and S. Bédard. 2017. The irregular shelterwood system as an alternative to clearcutting to achieve compositional and structural objectives in temperate mixedwood stands. For. Ecol. Manage. 398: 91-100. doi:10.1016/j.foreco.2017.04.042.

Raymond, P., A.A. Royo, M. Prévost and D. Dumais. 2018. Assessing the single-tree and small group selection cutting system as intermediate disturbance to promote regeneration and diversity in temperate mixedwood stands. For. Ecol. Manage. 430: 21-32. doi:10.1016/j.foreco.2018.07.054.
Raymond, P., S. Bédard, V. Roy, C. Larouche and S. Tremblay. 2009. The irregular shelterwood system: review, classification, and potential application to forests affected by partial disturbances. J. For. 107(8): 405-413. doi:10.1093/jof/107.8.405.

Reich, P.B., K.M. Sendall, K. Rice, R.L. Rich, L. Roy, A. Stefanski, S.E. Hobbie and R.A. Montgomery. 2015. Geographic range predicts photosynthetic and growth response to warming in co-occurring tree species. Nature Clim. Change. 5(2): 148-152. doi:10.1038/ nclimate2497.

Spathelf, P., A. Bolte and E. van der Maaten. 2015. Is Close-toNature Silviculture (CNS) an adequate concept to adapt forests to climate change? Landbauforsch 3/4(65): 161-170. doi:10.3220/ LBF1452526188000.

Ste-Marie, C., E.A. Nelson, A. Dabros and M.-E. Bonneau. 2011. Assisted migration: Introduction to a multifaceted concept. For. Chron. 87(6): 724-730. doi:10.5558/tfc2011-089.

Thiffault, N. and F. Hébert. 2017. Mechanical site preparation and nurse-plant facilitation for the restoration of subarctic forest ecosystems. Can. J. For. Res. 47(7): 926-934. doi:10.1139/cjfr-2016-0448.

Trumbore, S., P. Brando and H. Hartmann. 2015. Forest health and global change. Science 349(6250): 814-818. doi:10.1126/science.aac6759.

Urli, M., N. Thiffault, D. Houle, S. Gauthier and Y. Bergeron. 2020. Role of green alder in boreal conifer growth: competitor or facilitator? FACETS 5(1): 166-181. doi:10.1139/facets-2019-0064.

Webster, C.R. and N.R. Jensen. 2007. A shift in the gap dynamics of Betula alleghaniensis in response to single-tree selection. Can. J. For. Res. 37(3): 682-689. doi:10.1139/x06-267.

Williamson, T.B., J.R. Parkins and B.L. McFarlane. 2005. Perceptions of climate change risk to forest ecosystems and forest-based communities. For. Chron. 81(5): 710-716. doi:10.5558/tfc81710-5. Williamson, T.B., M.H. Johnston, H.W. Nelson and J.E. Edwards. 2019. Adapting to climate change in Canadian forest management: Past, present and future. For. Chron. 95(2): 76-90. doi:10.5558/ tfc2019-015. 